\title{
Agents of urban (in)security: contextualising the banning of political vigilantism in Ghana
}

\author{
Mariam Bjarnesen
}

Abstract: In 2019, a new law banning vigilantism was adopted in the West African nation of Ghana. The law followed years of debate and violent incidents related to the presence of informally mobilised so-called 'political vigilantes', charged with providing security during political events. At first glance, the ridding of such state-competing elements through legal measures appears unproblematic and in line with democratic values. However, as this article argues, by drawing on the case study of Ghana and the pre-2020 election phase, such legal actions against non-state actors can be problematic and, in the worst case, constitute a threat to security and stability if public trust in authorities and formal state security providers is not sufficiently solid. Grounded in a broader discussion on security in fragile contexts and urban centres on the African continent, this article analyses the consequences of banning vigilantism where formal security provision is weak or not fully trusted.

Keywords: Political vigilantism, foot soldiers, Ghana, election-related violence.

Note on the author: Dr Mariam Bjarnesen is a Senior Lecturer of war studies in the Department of Security, Strategy and Leadership at the Swedish Defence University. Her recent research focuses on postwar rebel networks, informal security provision, vigilantism and gender mainstreaming in military organisations. She is the author of Repurposed Rebels - Postwar Rebel Networks in Liberia (University of Georgia Press, 2020).

mariam.bjarnesen@fhs.se

(C) The author(s) 2021. This is an open access article licensed under a

Creative Commons Attribution-NonCommercial-NoDerivs 4.0 Unported License 


\section{Introduction}

No matter whether formal security providers are weak, unable, or perhaps even unwilling to cater for their citizens' everyday protection, people will not linger in a security vacuum. In such a context, people will turn to others who seek to fill the void. Non-state security actors, including those at times referred to as vigilantes, are often accused of undermining the state, causing mob violence and furthering insecurity. At the same time, vigilantism has been acknowledged as a justifiable alternative for citizens seeking protection in weak or predatory states (see for example Abrahams 1987; Buur 2006; Kantor \& Persson 2011; Kyed 2018). While questions of impunity and the lack of rule of law are not easily overlooked, such groups can, and do, form symbiotic relationships with state institutions and unofficially provide security alongside formal security actors (Buur \& Jensen 2004; Abrahams 1987; Buur 2006; Chabal \& Daloz 1999; Baker 2008; Kirsch \& Grätz 2010). Regardless of their composition or grounds for mobilisation, vigilantism is undoubtedly a complex phenomenon and the actions of vigilante groups and their effect on security remains highly contested, not least in urban African settings.

The complexity of vigilantism is visible in the findings of Helene Maria Kyed (2018), who uses the concept of 'street authority' while studying community policing in Mozambique and Swaziland. Kyed argues that street authority relies on the capacity for swift, direct actions, often through violent means, to enact order on the streets. The phenomenon emerges in urban contexts where poor urban citizens mistrust the state and where there is a preference for immediate outcomes due to livelihood uncertainties, low security and difficulties expressing grievances through official political channels. However, as Kyed points out, informal security providers can constitute more than an alternative to state police. They can also become politically significant, for instance to politicians who enrol the groups to advance their own political agenda (Kyed 2018: 19). This unavoidably leads to questions of whether, or perhaps when, such actors are best understood as agents of security or insecurity, with their often illegal, yet sometimes perceived as legitimate, practice. In emerging democracies, tensions are often particularly heightened during times of elections. Certain groups or minorities, perhaps tied together by ethnic background, religious or political views, or socio-economic status, may feel especially vulnerable. During such occasions, the mobilisation of informal groups by political actors is not uncommon. As noted by Burchard (2015: 19), in her analysis of electoral violence in Africa, there are many instances in which political actors mobilise supporters or hire gangs to terrorise electoral actors. Yet as addressed in this article, even if electoral victory is the ultimate aim behind such mobilisation, the use of these groups varies and may or may not include violence or intimidation. Against such a backdrop, a discussion of if, when, and how states should respond to these non-state actors becomes relevant. At first glance, the 
ridding of such state-competing elements in the security sector through legal measures appears unproblematic and in line with democratic values, based on the state's monopoly on the use of legitimate violence. However, this article draws on the case study of Ghana and the pre-2020 election phase - combining a review of existing scholarship and analysis of media reporting - to argue that such legal actions against non-state actors can be deeply problematic. In a worst-case scenario, such measures could present a threat to security and stability if public trust in authorities and formal state security providers is not sufficiently solid. Grounded in a broader discussion on security in fragile contexts and urban centres on the African continent, this article analyses the consequences of banning vigilantism where formal security provision is weak or not fully trusted.

Located in a sub-region historically plagued by civil wars, mercenaryism, authoritarianism and political instability, Ghana has stood out as a powerful exception when it comes to peace and stability, economic growth and democratic development. One often-praised factor is the country's record of successful elections; Ghana has experienced seven consecutive elections without large-scale violence (Ayee 2017; Graham et al. 2017). This makes Ghana rather unique in an African context. Yet despite these achievements, Ghana has not been spared from threats to its continued consolidation of democracy and stability. A frequently raised concern are the groups locally known as political vigilantes. Recruited by the major political parties or individual politicians, political vigilantes are informally mobilised groups of largely unemployed male youths. They have been charged with providing security during electoral campaigns and political events, and used to promote their political patrons (Bob-Milliar 2014; Gyampo et al. 2017). However, in mid-2019, Ghana adopted the new Vigilantism and Related Offences Act, banning vigilantism (Republic of Ghana 2019). The law followed years of debate and violent incidents related to political vigilantes, especially in the capital Accra and other urban centres of the country. In early 2019, more than twenty vigilante groups, connected to the main political parties in different ways, were reported active across Ghana (Myjoyonline 2019b). From an electoral security perspective, such mobilisation is, more often than not, deeply worrying. The political vigilantes in Ghana had also increasingly been accused of causing insecurity and violent riots (Kwarkye 2018). With an upcoming election in late 2020, they were believed to constitute an acute threat to stability and were accordingly banned.

Nevertheless, vigilantism is a highly relational phenomenon that must never be taken out of context. As emphasised by Kirsch \& Grätz (2010), what is needed in the analysis of vigilante action in sub-Saharan Africa is attention to its embeddedness in social contexts, and its relation to state agencies and other socio-political actors. As expressed by Gyampo et al. (2017: 113), vigilante groups do not arise in a vacuum. Following Abrahams' observations, vigilantism tends to occur on the edges of state influence and control (Abrahams 1987: 179). Vigilantism is accordingly a phenomenon 
best understood in the context of the state. Therefore, the overall aim of this article is to assess the banning of political vigilantes through a holistic approach, keeping in mind that these groups may not be the only security challenge Ghana is faced with, especially during elections. One incident that illustrates the complexity of such legislative actions is the shootings at the parliamentary by-election in the Ayawaso West Wougon constituency in the capital of Accra in January 2019. Masked men, which later investigations proved to be national security operatives of the Special Weapons and Tactics (SWAT) team, stormed the residence of the main opposition candidate and opened fire on party activists. Video footage of the violent scene, which included armed men, bullet holes, bloodstained walls and wounded civilians, soon went viral, while the opposition accused the government of orchestrating the attack (Bjarnesen 2020b). The incident revealed, as argued in this article, that political vigilantes, in all fairness, have not been Ghana's only security concern. Vigilante groups may act in predatory ways, but so too may formal security actors, perhaps especially in emerging democracies. In this light we can ask: does banning political vigilante groups actually solve Ghana's problem?

In this article, Ghana's history of political vigilantism is first addressed. While both violence and positive contributions of such groups will be acknowledged, the phenomenon of political vigilantism will be related to a broader discussion on vigilantism where security is fragile and where people, despite its perils, may find vigilantism a legitimate alterative to formal state action. The Ayawaso West Wougon violence and the legislative actions that were taken against political vigilantes after this incident will thereafter be further scrutinised. As concluded in this article, the banning of political vigilante groups does not offer a holistic solution to political instability and fragile urban security in Ghana, as such measures fail to address the reality of state complicity in violence and insecurity. Legislative measures must therefore also be assessed in the light of the actions of state-sanctioned security providers, as highlighted by the 2019 Ayawaso West Wougon shootings.

\section{Ghana's history of political vigilantism}

Following two and a half decades of military rule, political instability and multiple coups, Ghana consolidated its multi-party democracy through a number of electoral reforms implemented after $1992 .{ }^{1}$ Having gone through seven presidential and parliamentary elections resulting in three turnovers of political power in 2001, 2009 and 2017 between the two dominant parties, the National Democratic Congress (NDC)

${ }^{1}$ For an in-depth discussion on Ghana's past elections and post-independence political processes, see Ayee (2017). 
and the ruling National Patriotic Party (NPP), Ghana is now seen as a thriving African democracy (Gyampo et al. 2017: 24). What has further contributed to the praise of Ghanaian stability and democratic achievements is that these elections have been considered generally free and fair, spared from outbursts of large-scale violence. Ghana also has a vibrant media and civil society (Gyampo et al. 2017: 25). However, the issue locally known as political vigilantism or footsoldierism has haunted Ghanaian elections over the years and has been at the centre of political discussions of security, especially during elections. As noted by Bob-Milliar (2014: 126), competition between the two main parties has been relatively free of the high-intensity violence that has characterised multi-party elections in some parts of Africa. Nevertheless, the country has witnessed violent clashes between party activists. In Ghana's party system, foot soldiers - that is, rank and file party members - play a very important role in the electoral process. Political office-seekers have increasingly relied on the mobilisation abilities of these young men and women, raising questions and controversy over their central role in Ghana's democracy (ibid.).

Political vigilantism is by all measures not a new phenomenon in Ghana. Political vigilante groups mobilised by the political parties have been involved in all of Ghana's seven elections and three transitions since independence, and have had an active presence in all regions of the country (Gyampo et al. 2017: 118). The rise of the foot soldiers can be traced to the 1980s and 1990s and the emergence of door-to-door campaigns in rural areas and smaller cities throughout the country. This mass mobilisation of youth turned out to be a successful electioneering strategy, in which the party foot soldiers themselves were perceived to have contributed significantly to party political successes (Birikorang \& Aning 2016: 89). In cooperation with other party activists and youth wings, political vigilantes have also been active in election-related matters such as serving as polling agents or helping with voter registration. In providing these services around elections, they may be said to have encouraged fairness and transparency during all seven general elections in the Fourth Republic (Gyampo et al. 2017: 120).

Despite the positive roles that political vigilante groups can (and do) play in Ghana's elections, their involvement in violent incidents is what has recently drawn attention to them. Even though Ghana has been spared from large-scale election-related violence over the years, incidents of violent vigilantism have occurred before, during and after elections in the post-independence era (see for example KumahAbiwu 2017), particularly when supporters of the main parties have clashed with each other. Supported by party representatives, they have threatened, intimidated and assaulted opponents. They have also been guilty of assaulting electoral officials and vandalising registration centres (Kwarkye 2018). However, even though these violent incidents have led to the condemnation of political vigilantes, they have also highlighted the ambivalence of perspectives on the existence of such groups in Ghana, not 
least in political circles. For instance, in 2015 during a by-election in the Talensi constituency, the NPP-associated political vigilante group the 'Bolga Bull Dogs' clashed with the NDC-mobilised 'Azorka Boys' vigilante group after both sides accused each other of preventing party members from visiting the polling station (Emmanuel 2015). Sporadic shooting was also recorded around the NPP constituency office during the same event (Modern Ghana 2015). The incident caused the police to publicly condemn the actions of the political vigilante groups in a statement which emphasised 'that it is unlawful for political parties, groups, organisations or individuals to encourage the formation of vigilante groups and other associations that assume the character of a security organisation, unless that person, group or organisation has been granted a licence for that purpose under Police Service (Private Security Organisation) Regulation, 1992 (LI 1571)' (Myjoyonline 2015). Meanwhile, the Interior Minister, Mark Woyongo, instead indicated that the best way to solve the problem of vigilante groups was to legalise them. With an official licence as a security company, political vigilante groups such as the Azorka Boys and the Bolga Bull Dogs could be regulated, since they had in fact been operating as security companies, the minister frankly admitted in an interview (Citifmonline 2015).

In 2018, the opposition NDC announced its endorsement of the formation of new political vigilante groups through statements by the NDC General Secretary, Johnson Asiedu Nketia. The Greater Accra-regional organiser, Anthony Nukpenu, further stated that the NDC were to recruit 200000 'boys' into its newly formed vigilante groups (Mubarik 2018a). The endorsement was immediately condemned by the independent non-partisan governance institution, the National Commission for Civic Education, who took the opportunity to remind all political parties that they had a responsibility towards the preservation of peace, law and order, and should therefore disband all existing vigilante groups with immediate effect (ibid.). Asiedu Nketia defended the formation of the new vigilante groups as a natural response to the governing NPP's refusal to disband its own vigilante groups (Mubarik 2018b).

The violence of vigilante groups has also been internal, often related to claims of neglect of foot soldiers by their political patrons. In March 2017, following the NPP election victory which placed President Nana Akufo-Addo in power, the political vigilante group the Delta Force, aligned with the ruling party, turned against the NPP after the president's appointment of George Agyei as regional security coordinator for the Asante Region. The Delta Force strongly opposed Agyei's appointment as they were of the opinion that he had not contributed to the NPP victory and therefore did not deserve his new position. Delta Force members barged into Agyei's office, assaulting and ejecting him with force. Later in April 2017, when the accused Delta Force members were on trial for the incident, fellow foot soldiers entered the court, threatened the judge and freed their comrades (Kwarkye 2018). This was not the only time frustrated foot soldiers turned against their own party. Members of the NPP's 
Invisible Forces in July the same year besieged the office of the Eastern Regional National Health Insurance Scheme, claiming they could not work with the Regional Manager (Citifmonline, 2017). And during yet another incident the same month, other vigilante members associated with the NPP in the Ashanti Region stormed the premises of the Metro Mass Transit Bus terminal to stop the Regional Depot Manager from doing his job as they claimed their party had appointed him to the position illegally (ibid.).

Who, then, are these foot soldiers and what motivates them to join these groups? Empirical research among Ghana's political vigilante groups suggests that their members come from marginalised segments of the population. The popular image of foot soldiers, as Bob-Milliar (2014: 131-2) describes, is of heavily built 'macho' men. As residents of poor neighbourhoods or urban slums, they often lack secure employment and are forced to make a living through casual day jobs. Bob-Milliar's research suggests that party foot soldiers tend to be youths, informally recruited directly by an executive member of a political party or a party's candidates to assist them in attaining party or public office. They engage in political activities ranging from pro- or anti-government protests, political meetings, canvassing for votes, and exercising public authority by providing security for their communities. The more ambitious recruits are likely to formalise their membership with a political party. Those with exceptional mobilisation abilities and leadership qualities have a chance to move up the party ladder, either as youth or constituency organisers, or as local chairmen. Yet in general, the activism of party foot soldiers is very mobile and their engagement with the main parties is largely informal and highly personalised (ibid.).

\section{Underlying reasons for party mobilisation and acceptance of vigilantism}

As can be seen from Ghana's electoral history, there appear to be various and complex reasons behind the existence of vigilante groups and their continued use by politicians. Before going further, it should be noted that not all party foot soldiers are necessarily violent. According to Bob-Milliar (2014: 134-5), most party foot soldiers engage in non-violent political campaigning and behave like activists elsewhere in advanced democracies. As noted above, such political activism has been vital for past election victories on both sides. Nevertheless, NDC and NPP foot soldiers have increasingly been trained to operate as security agents for the party and political leadership during times of elections. This has been especially apparent for parties in opposition due to their lack of trust in state security agencies (Gyampo et al. 2017: 120). As I have argued elsewhere, such informal security roles often have a degree of local legitimacy (Bjarnesen 2020b). Although the presence of increasingly armed and trained vigilante groups acting as security operatives clearly raises questions of their legality, 
accountability, and their potential threat to Ghana's democratic foundations, this does not, I argue, erase the fact that even at the highest political level, the ability to cater for your own security can be vital. Such a practice may also contribute to democratic development if formal security actors are unable, or unwilling, to provide safe and secure environments for political contenders or the voting public. This argument is based on the historically ambiguous status of vigilantism in contexts where the state has had limited ability or will to protect its own citizens. As Bruce Baker (2008: 5-6) notes, the governance of policing, as an organised activity that can be conducted by both state and non-state groups seeking to maintain communal order, security and peace, is a contested terrain. Herein various nodes of governance bargain and negotiate between themselves over the nature of the order to be established and how protection is to be accomplished. On the African continent, multiple authorities and providers form a complex set of choices for ordinary people as they seek to negotiate a measure of protection from crime and abuse in their daily lives. Therefore, a focus on government agencies only tends to draw attention away from the full range of actors involved in security provision that exists, particularly at local levels (ibid.).

In other words, formal security providers are not the only ones citizens consider for their everyday protection. Nor are non-state alternatives always considered second best or morally wrong in the eyes of the public, whether legal or not. As Daniel Nina (2000: 20) notes, normative definitions of 'good' and 'bad' are historically bound and as such, they have a relational meaning. Accordingly, both what is 'good' and 'bad' is relative to who determines the social meaning of a community's behaviour. As a result, Nina argues, communities that engage in vigilante practice do so at the risk of being labelled 'bad' by the state, even when the state is unable to provide a safe and secure environment for the community. On the other hand, as found by Pratten (2008: 6) in his research on Nigerian vigilantes, most vigilante groups do invoke notions of themselves as the protectors of a 'moral community'. How these communities are constructed through vigilantism, and especially through the processes of boundary making in which they are engaged, is a central question, Pratten further suggests. As Tankebe (2009: 247) notes, when people believe that procedures are fairly administered, and that legal authorities are trustworthy, they are more likely to comply with the law and cooperate with legal authorities. On the other hand, perceptions of unjust procedures and untrustworthiness can lead to public unwillingness to cooperate with state security providers and general non-compliance with legal decisions. Accordingly, as Tankebe (2009: 249) argues, the public tendency to support vigilantism reflects, at least in part, public resentment against the perceived procedural injustice of the nation-state and its legal apparatus.

The mobilisation and acceptance of political vigilante groups in Ghana is better understood in such a light. Trust in the state's ability or will to deliver security and justice to all citizens, including those opposing ruling parties, is far from a given in 
many societies. This has been the case in Ghana, where political party representatives, and particularly those in opposition, have often stated that they would not demobilise their foot soldiers due to fears the other side would not follow suit. In March 2019, for instance, Joseph Yammin, NDC party representative and former Ashanti Regional Secretary, who has been identified as the main financier of the political vigilante group known as the Hawks, stated that the NDC had no plans whatsoever to disband their vigilantes. The Hawks, Yammin stated, was a taskforce recognised by the party, assigned to provide security during the elections for its party members (Ghanaweb 2019a). Other party representatives, however, reacted strongly against Yammin's statement. A public statement signed by NDC General Secretary Johnson Asiedu Nketia underlined that the position of the former deputy Ashanti regional minister did not represent the views of the party on the vigilante menace. Instead, the General Secretary stated that the party wished to reiterate its unwavering commitment to the process of disbanding all political vigilante or party militia groups in the country (Ghanaweb 2019b).

These statements provide further evidence of the ambivalent feelings many Ghanaians have about politically mobilised vigilantism. They reveal the internal power struggles around these groups and how they should be perceived and publically spoken about. Are these groups private protectors, ensuring the safety of the political opposition, or are they simply thugs or party militias, used by the political elite to terrorise the electorate and intimidate voters in order to attain state power? When it comes to how we define, frame and understand vigilantism, it is necessary, as noted by Sen \& Pratten (2007: 8), to account for the politics of language and how labelling is employed to legitimate or oppose vigilante activity. In the case of Ghana, the power dynamics of such labelling has been brought to light with the government's adoption of the recent law against political vigilantism. Political vigilantism has thereby been publically condemned. But the ruling party, just like the opposition, nevertheless has a long history of mobilising such groups. Therefore, it cannot be excluded that at least elements of the political elite will continue to do so in the future.

As much research on vigilantism has shown, the boundaries between state and non-state security actors are indeed very fluid. Buur \& Jensen (2004: 140) argue that even though vigilantism in different forms challenges the state and the rule of law, it cannot be reduced to expressions of the mob or antidotes to formal law. This is very much evident in the case of Ghanaian political vigilante groups who, as described above, have been more than simply a tool of the political opposition. Mobilised by the current governing political party, or by individual political representatives within the ruling party, they have had an undisputable direct link to the state. Against such a backdrop, to categorise these groups as entirely non-state actors is a mistake. Rather, they have been unofficial, yet highly controversial, state- as well as oppositionalinstruments used to preserve or gain state power. Given this logic of vigilantism, it 
is rather obvious why opposition parties might feel the need to mobilise their own informal security structures in times of elections. Ruling parties, however, could be seen as not sharing this incentive for this type of mobilisation, given their links to formal security providers who could defend them against election-related harassment. However, Ghanaian elections have historically been extremely close between the two dominant parties. In the 2000 elections, the NDC just barely lost to the NPP, with an even closer race in 2008 as the NDC retook power. As Whitfield (2009: 622) has argued, the competitive nature of the Ghanaian elections is linked to the fact that both the NDC and the NPP serve as credible opposition and both parties have established institutional networks in all regions of the country. But as Whitfield (2009: 623) further notes, the outcomes of elections have been determined by swing regions, which contain large numbers of floating voters who are not party loyalist and may cast their votes based on government performance. Given such circumstances, and given the rather unpredictable power balance between the two leading parties, it is perhaps not surprising that both would go to extremes to win voters, including the mobilisation — sometimes violently —of political vigilantes.

As argued by Paalo (2017: 6), the risk of election-related violence may be higher where there is intensive political competition and parties have real opportunity to change existing power dynamics, as in the case of Ghana. Given such a political landscape, the issue of political vigilantes becomes even more relevant. In Ghana it is ordinarily expected that the more effective the youth machinery of a party, the more sympathisers it will attract, and ultimately the higher its chances of acceding to power (Paalo 2017: 5). Therefore, despite official rhetoric during the pre-election phase in 2020 in which both parties stated their willingness to abandon engagements with political vigilante groups - which were attracting potentially influential youth - there was good reason to suspect that at least some party elements would hesitate to do so. In the next section, we turn to the Ayawaso West Wougon incident to further illustrate why the banning of political vigilantes is an insufficient response to Ghana's fragile security environment, especially in times of elections.

\section{The 2019 Ayawaso West Wougon violence and its aftermath}

It was only an hour or so after the commencement of voting at the La Bawalashie Presbyterian School Polling Station that chaos erupted, during the by-election for the Ayawaso West Wuogon Constituency in the Ghanaian capital Accra on 31 January 2019. Pulling up in SWAT-branded vehicles, masked men wearing national security apparel allegedly stormed the residence of the NDC candidate Delali Kwasi Brempong, not far from the polling station, and opened fired on NDC activists who had gathered for the elections in support of their party (Bjarnesen 2020b). The 
incident, leaving at least six people critically injured from gunshots, was one of many shedding new light on electoral insecurity in Ghana. The turbulent by-election also gave the already widely debated issue of political vigilantism new energy. The passing of the Vigilantism and Related Offences Act was directly linked to the violent turn of events at the Ayawaso West Wougon by-election. But why was this the only substantial consequence of the incident? The investigations that followed shed light on Ghana's problem with party foot soldiers. Yet the presence and actions of masked gunmen in national security apparel and state-branded vehicles at the scene reveals that Ghana's security challenges go beyond political vigilante groups and cannot be understood in isolation from the state.

The Ayawaso West Wougon incident underlines that vigilantism, political vigilantism and the phenomena of all forms of informally mobilised security structures must be analysed in relation to the state. The question of the state is always present in these issues, whether by its absence, its silent approval or usage of these structures, or its fight against the very existence of these informal actors. Policing in such a context furthermore becomes a major concern. In Ghana, the status, performance and legitimacy of the police force is very much related to the activities of informal security providers, including the political vigilante groups and especially in urban centres. As noted by Tankebe (2009: 250-1), vigilantism is commonly seen as a direct outcome of chronic policing failure in the provision of physical security. Accounts of vigilantism on the African continent also illustrate the importance of different forms of police corruption as explanatory factors. Violent self-help, as Tankebe calls it, becomes an attempt to compel the police to bridge the gap between what people might consider to be their socially established entitlement to procedurally fair treatment and their perceived abusive or neglectful treatment by the police (ibid.). When it comes to the Ghanaian police force, it is clear that major problems have had a bearing on the climate of political vigilantism in the country.

As noted by Aning \& Albrecht (2020), Ghana is showing signs of tension in the political system that is reflected in increasing political interference in how the police operates. Recruitment into the police, Aning and Albrecht find, depends on knowing a person who has political connections. This, they argue, was not the case in the past. As their informants state, only those affiliated with the party in power have a chance of employment within the police. This development has been accompanied by interference by powerful individuals, often politicians, over who can and should be arrested, investigated and ultimately prosecuted. As a result, confidence in the Ghanaian police is at an all-time low, both among politicians and in the wider population. According to Aning and Albrecht, political vigilantism in the country and the situation within the police force are intimately linked. The increasing public distrust of police due to their politicisation has resulted in political parties' mobilisation and consolidation of political vigilantes. Not only have these groups been better equipped than the average 
police unit; the police are under such considerable political control that they have been unable to confront these politically motivated and controlled security groups (Aning \& Albrecht 2020).

Accordingly, any assessment of the threat to stability, security and the overall democratic process in Ghana that political vigilantism and the militarised party foot soldiers constitute must be conducted from a holistic perspective, also taking the composition and actions of formal security providers, especially in times of elections, into consideration. The Ayawaso West Wougon shooting is a vivid example of this. In an attempt to calm the Ghanaian population, and perhaps as a show of force when it came to electoral security, the NPP government set up the Emile Short Commission, a three-member committee tasked with conducting a full and impartial inquiry into the events and associated violence of the by-election. The commission was to identify any person responsible for or involved in the incident and to inquire into any matter it considered related to its causes (Myjoyonline 2019a). Public hearings followed in mid-February 2019, with the commission given one month to complete its work. The NDC, who from the start had accused the government of unleashing the violence, expressed great distrust in the process. General Secretary of the NDC, Asiedu Nketia, remarked that the commission was only a ploy to protect the real perpetrators and a smokescreen used by the president to protect his own appointees. Nketia further underlined that his party was concerned that no arrests had been made despite video evidence of brutality by security personnel (Adogla-Bessa 2019). Despite opposition fears, the formal security institutions were scrutinised during hearings. It became clear that the presence of politically assigned foot soldiers in times of elections were not the only elements with the potential to disturb the democratic process. The actions of the SWAT team and its lack of coordination with other security institutions were clearly problematic. As noted by security analyst Kwesi Aning during the hearings, the creation of militias was very worrying, but even more disturbing was the undermining of the statutory functions of the National Security Council. According to Aning, the formation of a non-recognised quasi-statutory SWAT posed a danger to security services and undermined loyalty, and it was particularly concerning that statutory forces did not know of the existence of other forces who can be commanded to perform in the public space (GBN 2019). Rumours about who the individuals of the SWAT team were and on what grounds they had been recruited also came to factor in the debate about the Ayawaso West Wougon violence. Sam George, Member of Parliament and NDC representative, was attacked and reported that his assailants were members of the NPP vigilante group 'Invincible Forces' in National Security Council attire (Peacefmonline 2019). During the commission's hearing, National Security Minister Albert Kan-Dapaah denied that the masked men behind the Ayawaso West Wougon shootings were members of the NPP vigilante group but admitted that some may formerly have been members. (Modern Ghana 2019). 


\section{The Short Commission Report and the government response}

In mid-March 2019, the commission of inquiry submitted its report with recommendations for further actions due to the violent abuses committed during the Ayawaso West Wougon by-election. Yet it was not until September that the government made the report public after much pressure by the opposition. According to NDC representative Sam George, the government was trying to avoid incriminating itself given what he believed was the damning nature of the report on the national security apparatus. He further added that he expected nothing but a 'cover up' by the government as hooligans had been incorporated into the state security apparatus to perpetrate violence (Prime News Ghana 2019). Nevertheless, as the report finally was made public (Short Commission Report 2019), it was clear that the national security apparatus had not been able to avoid criticism. The commission found that the SWAT team had used civilians whom they had armed and put in official uniforms but who were not subject to any regime of accountability. The Minister of National Security and his team therefore ought to explain how this force could operate outside any rules of accountability in respect of the use of firearms, the commission emphasised. Additionally, the commission found that the national security establishment is a means by which the party faithful are resettled. Whether or not these persons who perform vigilante functions are members of any known militia group, the commission stressed, their very presence within the state security machinery encourages opposition parties to counter their activities. The current situation, the commission found, reflects a transition in which members of a party militia are ordinarily appointed as national security operatives upon the assumption of power by their political party. This undermines the standing and future of the security sector, but also the individual and collective security of Ghanaians if left unchecked, the commission argued (Short Commission Report 2019).

Accordingly, the commission did not refrain from strongly criticising the Ministry of National Security establishment and individual representatives within it at different levels, and nor did they spare strong words against the actions of the SWAT team during the by-election. The commission nevertheless emphasised the overall problem with mobilisation of what they referred to as 'militia organisations' by political parties or individual politicians, recommending the immediate criminalisation of the establishment and funding of such elements in Ghana. The commission found that these groups were a challenge to state authority and a threat to the very stability of Ghana's constitutional democracy. It observed that they were maintained by the parties and private owners for a variety of purposes but were united by one overarching goal: to defend the interests of their political parties by every means, including through the use of unauthorised force. The commission further rejected the labelling 
of these groups as 'vigilantes' given their lawless manner and non-cooperative attitude towards regular law enforcement bodies (Short Commission Report 2019).

As the Ghanaian government finally made the Short Commission Report available to the public, they simultaneously published a White Paper as a response to the investigations. It made clear that the government did not accept the commission's version of events during the Ayawaso West Wougon by-election. As stated in the White Paper, the government claimed that the commission had failed to follow its most critical terms of reference, which was to make a full and faithful impartial inquiry of what had occurred. The White Paper stated that the government was accordingly unable to fully accept the findings and recommendations of the report (Republic of Ghana, White Paper 2019). However, the government did underline that it was indeed committed to act against politically sponsored vigilantism, as the parliament had passed the Vigilantism and Related Offences Act (Act 999), 2019, initiated by the president to disband and prohibit vigilante groups and their activities.

The government's response to the investigation and the strong critique against the security establishment reveals how very politicised the issue of vigilantism in Ghana is. While the government's willingness to deal with the political vigilante groups could be seen as a move in the right direction, their unwillingness to acknowledge state complicity in the violence and pre-election tensions is nevertheless clearly problematic. Accordingly, the next section explores why the banning of vigilantism may not be the answer.

\section{Why banning vigilantism may not be the answer}

While the banning of political vigilantism in Ghana may appear as the only sensible response to the violence of such groups during elections, it cannot be taken for granted that such legislative measures would lead to increased electoral security and the continued consolidation of the democratic process. By using the Ayawaso West Wougon by-election as an empirical example, this article has brought to light underlying problems and complex dynamics between formal and informal actors active within the Ghanaian security arena as well as on the political scene. There are at least two key reasons, drawing from this analysis, that suggest that the legislation alone will be limited in its effectiveness.

First, the party in power may seek to circumvent the legislation by formally incorporating vigilante groups into the state security sector, leading the opposition to counter by maintaining their own groups. Despite the opposition's initial doubt that the government-appointed commission would conduct an independent and impartial investigation of the events leading up to the violent election day, the commission did not refrain from criticising the government and the national security establishment 
in particular. The findings regarding recruitment into the formal security forces, such as the SWAT team, particularly speak to the argument of this article. If indeed the vigilante groups of the ruling NPP were incorporated into formal security structures based on loyalty rather than on merit, the banning of vigilantism is placed in an entirely different light. Even if both the ruling NPP and the opposition NDC were to disband their militarised foot soldiers, the NPP could in practice simply incorporate their own loyal 'macho men' into the formal security structures of the country. This would be an advantage out of reach for the opposition (whether the NPP or the NDC). Given that both sides competing for state power have a long history of distrusting their opponents, there would be little sense - from their perspective - of demobilising their informal security structures, as long as the capacity and legitimacy of the national security system is questioned, and those in power could formalise their vigilante groups. In this respect, the government's initiative to ban vigilantism may be regarded as a show of force and a diversion, which in practice could conceal a continued usage of party foot soldiers by giving them official status as formal security providers, while hindering the opposition from doing the same.

If electoral security is truly to be achieved in Ghana, the issue of political vigilantism cannot be allowed to overshadow underlying problems causing this phenomenon. If the question of the capacity and legitimacy of state security forces is one of those underlying problems, a second problem has its roots in the bigger question of why typically young, marginalised men become party foot soldiers and why they have increasingly resorted to violence and intimidation. According to Bob-Milliar (2014: 127), the normative logic of 'winner-takes-all' party politics contributes to low-intensity electoral violence. The political system where the winner monopolises all state power both comforts and discomforts political activists. As Bob-Milliar argues, this is linked to foot soldiers' aggression due to structural and partisan factors such as youth unemployment, unfulfilled electoral promises and survival strategies of elite groups. In such a political system, young party foot soldiers will place a high premium on capturing state power for the political elites. Accordingly, in political systems where so much is at stake, and so little is left for the losers, the risk of violence, particularly during elections, is indisputably high. With few other opportunities, loyalty to a political patron who succeeds in the political contest can give advantages to this marginalised segment of the population that they could otherwise only dream of. As we learn from the work of Gyimah-Boadi (2007: 24), patronage has been and remains the enduring characteristic of Ghanaian politics. As Gyimah-Boadi recalls from growing up in Ghana, one phrase repeatedly heard and associated with the political patronage system was 'unflinching support'. He has continued to hear that phrase throughout his adult life and it is always said in the context of swearing undying loyalty to the government of the day - military or civilian, authoritarian or democratic - and to the political personage, ideologies, policies and programmes they represent. Unflinching 
support in this context can be seen as a currency used in exchange for political favours (ibid.) This is perhaps most visible in times of elections. As Gyimah-Boadi (2007: 29) furthermore notes, elections in Africa continue to significantly reflect the overwhelming advantage incumbent parties enjoy over patronage resources. This allows the ruling party to use subtle and crude means to disorganise and destroy opposition parties, which can include the deployment of state security agencies to harass opponents. In such a context, it is easy to see how patronage capacity becomes the single most important factor in electoral outcomes. And in this light, it is equally easy to understand why the incumbent party becomes preoccupied with building patronage capacity immediately after elections as a method of political consolidation.

In December 2020, Nana Akufo-Addo won re-election with 51.59 per cent of the vote. The Ghanaian Police Service said it recorded more than 60 incidents during the elections. Twenty-one of them were reported to be true cases of electoral violence, six of which involved gunshots resulting in the death of five individuals (Aljazeera 2020). The European Union's chief observer, Javier Nart, stated that 'Ghanaians voted freely ... While there were isolated violent incidents, both on election day and during the campaign ... fears of violence and vigilantism, fortunately, didn't materialise. They were minor isolated incidents, some of them tragic ones' (ibid.). The banning of vigilantism did at best reduce the mobilisation of groups of potentially violent young men during the elections. This may have led to less violence, threats and intimidation. The use of legislative measures thereby appears to be the most sensible way of dealing with the issue of political vigilantism. However, this article has shown at least two underlying problems the act against vigilantism will not be able to solve: the issue of distrust in the formal security agencies, and the marginalisation and lack of other opportunities to make a living which lead youth to mobilise in the first place.

\section{Concluding remarks: who are the agents of urban (in)security?}

As Kumah-Abiwu (2017: 181) has argued, the fear of violence that has been associated with almost every election in Ghana raises questions about the strength and future directions of the country's democratic institutions and its political culture. As he finds, there is no doubt that the responsibility of preserving Ghana's democratic state lies in the hands of every Ghanaian, but the two major parties - the NDC and the NPP - must take greater responsibility by deepening the trust and respect for each other and the electoral institutions. The new law from 2019 banning political vigilantism does, at least at first glance, look like such an effort as both parties have officially stated that they are ready to disband these potentially violent groups for the sake of electoral security and Ghana's consolidation of the democratic process. However, we cannot disregard the risk that by initiating this law, the government uses 
democratic means in a way that undermines democratic values in the long term. Using the Ayawaso West Wougon by-election as an empirical example, it becomes clear that political vigilantes are not the only threat to further democratic gains in Ghana. The use of the national security agencies, such as the SWAT team during that day of voting, was indeed deeply concerning. Even more so was the government's unwillingness to address the criticism that followed this incident, not least the recommendations from the Emile Short Commission that implicated their own national security establishment. For young party foot soldiers, loyalty to the right political patron is vital. If they are loyal to the party securing state power, there is a chance to advance within the system, even for these marginalised youth, as evidence presented in the Ayawaso West Wougon hearings indicated. In a winner-takes-all political system this is deeply problematic for those who have supported the opposition. I have noted a similar logic in Liberia during the 2011 elections (Bjarnesen 2020a). Here informally mobilised security providers, consisting of mainly ex-combatants from the Liberian civil war, were mobilised as private security and party activists for the presidential candidates. For the ex-combatants, the elections provided them with promises and opportunities they otherwise lacked. But 'going into politics', as these men called it, was a dangerous game. If their political patrons managed to secure an election victory, this could lead to formal employment within the state security system. But if not, this would leave them even worse off than before the elections, making them vulnerable to harassment by the winners in power. The same dynamic can be discerned in Ghana.

Following the logic of vigilantism, it is not hard to understand the creation of informal security structures where the formal ones are not present, lack capacity, or are distrusted by the public. We therefore cannot take it for granted that political vigilante groups by default are agents of urban insecurity needing to be demobilised at all costs. Vigilante groups are accordingly not easily categorised as either good or bad. Their presence, actions, and their status as potential threats to, or facilitators of, security or even democracy must always be analysed and judged in relation to the state's performance and legitimacy. Hence, the question is not whether such actors should be banned or not. Rather, the question is why there is a perceived need for such actors in the first place. As the political climate in Ghana is characterised by suspicion between the main political opponents, it is not surprising that especially those in opposition have mobilised their own informal security apparatus. As noted by Kyed and Albrecht (2014), how and by whom a particular order is enacted in urban spaces is contested, and at times violently so. No one set of actors monopolises the authority or sovereign position to enact order, leading to reoccurring negotiations over the very definition of what that order is (ibid.). Informal security providers can fill an important function in fragile contexts and emerging democracies when it comes to the establishment of order, protecting the interests of those who feel they lack the protection of the state. More recently, Kyei \& Berckmoes (2021: 335) even argue that political 
vigilante groups allow voices otherwise not heard to be taken into account in the political field. Political vigilantism, they state, is a mark of refusal on the part of some of the citizenry to accept the political exclusion enforced on them by the state (Kyei $\&$ Berckmoes 2021: 324). Therefore, they conclude that political vigilantism enhances, rather than destroys, democratic governance (Kyei \& Berckmoes 2021: 335).

However, as Ghana's political vigilantes often have acted like party militias, not refraining from the use of violence if it serves the political interest of their own party, they have drifted further away from the protectors of democracy they potentially could be. In the urban context of Ghana, where they have been particularly active, the political vigilante groups have often contributed to the insecurity they also have the capacity to challenge. Yet banning them does not solve the problem because the problem is much more complicated than such legislation suggests. As Ghanaian journalist Manasseh Azure Awuni (2020) has argued, while the 2020 elections were celebrated as a victory for Ghana, this is actually because the death and destruction were insignificant compared to other countries on the continent. As Awuni rightly points out, there is more to democracy than holding peaceful elections. And holding elections without killing or maiming or burning houses should not be a considered a monumental achievement (ibid.). As can be seen from the Ayawaso West Wougon violence, national security agencies have contributed to electoral and overall insecurity in Ghana. For this reason, the banning of vigilantism is paradoxically problematic despite the relatively peaceful elections of 2020. Such legislative measures can function as a decoy for the opposition to disband those who in theory could protect oppositional political views, while allowing the government to circumvent the ban through formalising their own informal groups. Such a scenario is a threat to peace, stability and further democratic consolidation in Ghana beyond the elections of 2020.

\section{References}

Abrahams, R. (1987), 'Sungusungu: Village Vigilante Groups in Tanzania', African Affairs, 86(343): 179-96.

Adogla-Bessa, D. (2019), 'Ayawaso Violence: Emile Short Commission Begins Public Hearings Today', 14 February. Available at: https://citinewsroom.com/2019/02/ ayawaso-violence-emile-short-commission-begins-public-hearings-today/

Aljazeera (2020), 'Ghana President Nana Akufo-Addo Wins Re-election as 5 Killed', 9 December. Available at: https://www.aljazeera.com/news/2020/12/9/ five-killed-in-ghana-election-violence-as-accusations-continue

Aning, K. \& Albrecht, P. (2020), 'Vigilante Groups of Ghana's Political Parties Pose a Serious Threat to Security in the Country'. Available at: https://www.diis.dk/en/research/ vigilante-groups-of-ghanas-political-parties-pose-a-serious-threat-to-security-in-the-0

Ayee, J. (2017), 'Ghana's Elections of 7 December 2016: A Post-mortem', South African Journal of International Affairs, 24(3): 311-30. 
Awuni, M.A. (2020), 'Opinion: Ghana's Peaceful Elections Mask a Weak Democracy', 9 December. Available at: https://www.dw.com/en/opinion-ghanas-peaceful-elections-mask-a-weak-democracy/a-55885924

Baker, B. (2008), Multi-choice Policing in Africa (Uppsala, Nordiska Afrikainstitutet).

Birikorang, E. \& Aning, K. (2016), 'Negotiating Populism and Populist Politics in Ghana, 1949-2012', in K. Aning \& K. Danso (eds), Managing Election-related Violence for Democracy and Stability in Ghana (Ghana, Friedrich Ebert Stiftung), 61-96.

Bjarnesen, M. (2020a), Repurposed Rebels - Postwar Rebel Networks in Liberia (Athens GA, The University of Georgia Press).

Bjarnesen, M. (2020b), 'The Foot Soldiers of Accra', African Affairs, 119(475): 296-307.

Bob-Milliar, G.M. (2014), 'Party Youth Activist and Low-Intensity Electoral Violence in Ghana: A Qualitative Study of Party Foot Soldiers Activism', African Studies Quarterly, 15(1): 125-52.

Buur, L. (2006), 'Reordering Society: Vigilantism and Expressions of Sovereignty in Port Elizabeth's Townships', Development and Change, 37(4): 735-57.

Buur, L. \& Jensen, S. (2004), 'Introduction: Vigilantism and the Policing of Everyday Life in South Africa', African Studies, 63(2): 139-52.

Burchard, S. (2015), Electoral Violence in Sub-Saharan Africa: Causes and Consequences (London, Lynne Reinner Publishers Inc.).

Chabal, P. \& Daloz, J-P. (1999), Africa Works - Disorder as Political Instrument, African Issues (Oxford and Bloomington, IN, The International African Institute in association with James Currey and Indiana University Press).

Citifmonline (2015), 'We'll License Azorka Boys, Bolga Bulldogs - Interior Minister', 8 July. Available at: http://citifmonline.com/2015/07/well-license-azorka-boys-bolga-bulldogs-interior-minister/

Citifmonline (2017), '18 Incidents of Vigilante Violence Recorded since NPP's Victory', 26 October. Available at: http://citifmonline.com/2017/10/18-incidents-of-vigilante-violence-recordedsince-npps-victory/

Emmanuel, K. (2015), 'NPP "Bolga Bull Dogs" Clash with NDC "Azorka Boys", Pulse News, 7 July. Available at: https://www.pulse.com.gh/news/talensiby-election-npp-bolga-bull-dogs-clash-with-ndc-azorka-boys/0s08c4t

Ghana Business News (GBN) (2019), 'Security Expert Expresses Worry over SWAT Team', 5 March. Available at: https://www.ghanabusinessnews.com/2019/03/05/securityexpert-expresses-worry-over-swat-team/

Ghanaweb (2019a), 'NDC Will Not Disband Hawks Today, Tomorrow or Ever! - Yammin Replies Akufo-Addo, NPP', 11 March. Available at: https://www.ghanaweb.com/GhanaHomePage/ NewsArchive/NDC-will-not-disband-hawks-today-tomorrow-or-ever-Yammin-replies-AkufoAddo-NPP-729420

Ghanaweb (2019b), 'NDC Disowns Yammin over Vigilantism Comment', 13 March. Available at: https://www.ghanaweb.com/GhanaHomePage/NewsArchive/NDC-disowns-Yammin-over -vigilantism-comment-729982

Graham, E., Van Gyampo, R. \& Yobo, E. (2017), 'Ghana’s 2016 General Election: Accounting for the Monumental Defeat of the National Democratic Congress (NDC)', Journal of African Elections, 16: 24-45.

Gyampo, R.E., Graham, E. \& B.E. Asare (2017), 'Political Vigilantism and Democratic Governance in Ghana's Fourth Republic', African Review, 44(2): 112-35.

Gyimah-Boadi, E. (2007), 'Political Parties, Elections and Patronage: Random Thoughts on Neopatrimonialism and African democratization', in M. Basedau, G. Erdmann \& A. Mehler (eds), Votes, Money and Violence: Political Parties and Elections in Sub-Saharan Africa (Uppsala, Nordiska Afrikainstitutet and University of Kwazulu-Natal Press), 21-33.

Kantor, A. \& Persson, M. (2011), 'Liberian Vigilantes: Informal Security Provision on the Margins of Security Sector Reform' in M. Ekengren \& G. Simons (eds.) The Politics of Security Sector 
Reform: Challenges and Opportunities for the European Union's Global Role (Farnham, Ashgate), 273-304.

Kirsch, T.G. \& Grätz, T. (eds) (2010), Domesticating Vigilantism in Africa (Suffolk and Rochester NY, James Currey).

Kumah-Abiwu, F. (2017), 'Issue Framing and Electoral Violence in Ghana: A Conceptual Analysis', Commonwealth \& Comparative Politics, 55(2): 165-86.

Kwarkye, S. (2018), 'Political Vigilantism Threatens Stability in Ghana', Institute for Security Studies (ISS). Available at: https://issafrica.org/iss-today/political-vigilantism-threatens-stability-in-ghana

Kyed, H.M. (2018), 'Street Authorities: Community Policing in Mozambique and Swaziland', Political and Legal Anthropological Review, 41(S1): 19-34.

Kyed, H.M. \& Albrecht, P. (2014), 'Introduction: Policing and the Politics of Order-making on the Urban Margins', in P. Albrecht \& H.M. Kyed (eds), Policing and the Politics of Order-making (London, Routledge), 1-23.

Kyei, J.R.K.O. \& Berckmoes, L.H. (2021), 'Political Vigilante Groups in Ghana: Violence or Democracy?', Africa Spectrum, 55(3): 321-38.

Modern Ghana (2015), 'Talensi By-Election: NDC's Azorka Boys Clash with NPP’s Bolga Bull Dogs', 7 July. Available at: https://www.modernghana.com/news/628189/talensi-by-election-ndcs-azorkaboys-clash-with.html

Modern Ghana (2019), 'Ex-Vigilante Group Members Maybe Part of SWAT Team - Minister', 14 February. Availableat:https://www.modernghana.com/news/915826/ex-vigilante-group-membersmaybe-part-of-swat-team.html

Mubarik, A. (2018a), 'NDC to Recruit 200,000 Boys into Newly Formed Vigilante Groups', 9 September. Available at: https://www.pulse.com.gh/news/politics/ security-ndc-to-recruit-200000-boys-into-newly-formed-vigilante-groups/56v2gbx

Mubarik, A. (2018b), 'IGP Supports Vigilante Groups- Asiedu Nketia tells NCCE', 8 September. Available at: https://www.pulse.com.gh/news/politics/ vigilantism-igp-supports-vigilante-groups-asiedu-nketia-tells-ncce/kqsbrz4

Myjoyonline (2015), 'Police Declare Azorka Boys, Bolga Bull Dogs as Outlaws', 8 July. Available at: https://www.myjoyonline.com/news/police-declare-azorka-boys-bolga-bull-dogs-as-outlaws/

Myjoyonline (2019a), 'Emile Short, 2 Others to Investigate Ayawaso West Wuogon Violence', 6 February. Available at: https://www.myjoyonline.com/news/emile-short -2-others-to-investigate-ayawaso-west-wuogon-violence/

Myjoyonline (2019b), 'Security Analyst Names 24 Violent Groups in Ghana', 4 March. Available at: https://www.myjoyonline.com/security-analyst-names-24-violent-groups-in-ghana/

Nina, D. (2000), 'Dirty Harry is Back: Vigilantism in South Africa - The (Re)emergence of the "Good" and "Bad" Community', African Security Review, 9(1): 18-28.

Peacefmonline (2019), 'NPP Invisible Forces Fired Several Shots At Me . . - Sam George', 31 January. Available at: https://www.peacefmonline.com/pages/politics/politics/201901/373981.php

Pratten, D. (2008), 'The Politics of Protection: Perspectives on Vigilantism in Nigeria', Africa, 78(1): $1-15$.

Prime News Ghana (2019), 'Gov’t Hasn’t Shown Any Willingness to Release Ayawaso Violence Reports - Sam George', 6 September. Available at: https://www.primenewsghana.com/politics/gov-t-hasnt-shown-any-willingness-to-release-ayawaso-violence-reports-sam-george.html.

Republic of Ghana (2019), 'White Paper on the Report of the Commission of Inquiry into the Ayawaso West Wuogon Events', 13 September, (Accra, Government Printer Assembly Press).

Republic of Ghana (2019), 'Vigilantism and Related Offences Bill', L.I. 16/2019. Available at: https:// drive.google.com/file/d/1jzMV7ehFkGJwaPLz0HCwdJZamZ8ej1iB/view

Paalo, S. (2017), 'Political Party Youth Wings and Political Violence in Sub-Sahara Africa: A Case of Ghana', International Journal of Peace and Development Studies, 8(1): 1-14. 
Sakwaba Akwa, N. (2019), 'SWAT Team May Include Ex-vigilante Group Members - Kan-Dapaah', Myjoyonline.com, 14 February. Available at https://www.myjoyonline.com/politics/2019/ February-14th/swat-team-may-include-former-members-of-vigilante-groups-kan-dapaah.php

Sen, A. \& Pratten, D. (2007), 'Global Viglantes: Perspectives on Justice and Violence', in D. Pratten \& A. Sen (eds), Global Vigilantes (London, HURST Publishers Ltd), 1-21.

Short Commission Report (2019), 14 March. Available via Modern Ghana's webpage: https://cdn. modernghana.com/images/content/report_content/919201925357-1j041q5ccw-ayawaso-westwuogon-commission-of-inquiry-march-2019.pdf

Tankebe, J. (2009), 'Self-Help, Policing, and Procedural Justice: Ghanaian Vigilantism and the Rule of Law', Law \& Society Review, 43(2): 245-70.

Whitfield, L. (2009), "Change for a Better Ghana”: Party Competition, Institutionalization and Alternation in Ghana's 2008 Elections', African Affairs, 108(433), 621-41.

To cite the article: Mariam Bjarnesen (2021), 'Agents of urban (in)security: contextualising the banning of political vigilantism in Ghana', Journal of the British Academy, 9(s11): 19-39.

DOI https://doi.org/10.5871/jba/009s11.019

Journal of the British Academy (ISSN 2052-7217) is published by

The British Academy, 10-11 Carlton House Terrace, London, SW1Y 5AH

www.thebritishacademy.ac.uk 